\title{
Improving mold powder through crystallization using calcium fluoride and manganese oxide for continuous casting of steel
}

\author{
Ahmadreza AREFPOUR*, Leila SHAMS SOOLARI, Ahmad MONSHI \\ Department of Materials Engineering, Najaf Abad Branch, Islamic Azad University, Isfahan, P.O. Box 517, Iran
}

Received: July 29, 2013; Revised: December 08, 2013; Accepted: January 02, 2014

(CThe Author(s) 2014. This article is published with open access at Springerlink.com

\begin{abstract}
Mold powder is generally made of $\mathrm{SiO}_{2}$ and $\mathrm{CaO}$ with little amount of calcium fluoride $\left(\mathrm{CaF}_{2}\right)$ and carbon. Basically, $\mathrm{F}^{-}$has a crucial effect on viscosity and crystallization of the powder. However, emission of toxic materials containing $\mathrm{F}^{-}$constituent such as $\mathrm{HF}$ and $\mathrm{SiF}_{4}$ leads to serious environmental pollution. Overall, six powder samples were made during this research to study the effects of such compounds as calcium fluoride $\left(\mathrm{CaF}_{2}\right)$ and manganese oxide $(\mathrm{MnO})$ on the crystallization of mold powder and compare with that of the original mold powder. Having considered the chemical compounds of these six samples, two were finally chosen: powder sample A and powder sample E. The former was a simulated sample of the original mold powder using $\mathrm{CaF}_{2}$, and the latter was a less- $\mathrm{F}^{-}$sample in which $\mathrm{MnO}$ was used as a substitution for $\mathrm{F}^{-}$in the compounds of the mold powder. In other words, the amount of $\mathrm{F}^{-}$was cut in half comparing to that of the original mold powder. The thermal gravimetric analysis (TGA) was performed on the original mold powder, the simulated sample of the original mold powder and the less- $\mathrm{F}^{-}$sample. The results of the TGA demonstrated the reduction of thermal loss in samples A and E comparing to the original mold powder. On the other hand, the results of differential thermal analysis (DTA) of these three samples, i.e., original mold powder and samples A and E, demonstrated that melting and crystallization temperatures of the original mold powder were similar to those of samples A and E. Therefore, it can be concluded that samples A and E are potential laboratory-scale substitutions for the original mold powder.
\end{abstract}

Keywords: mold powder; crystallization; calcium fluoride $\left(\mathrm{CaF}_{2}\right)$; manganese oxide $(\mathrm{MnO})$

\section{Introduction}

Mold powder is mainly composed of $\mathrm{SiO}_{2}, \mathrm{CaO}, \mathrm{Al}_{2} \mathrm{O}_{3}$, $\mathrm{Na}_{2} \mathrm{O}$ with little amount of $\mathrm{F}^{-}$and carbon [1-3]. The powder has a crucial role in the stability of the process and the final quality of the production in continuous casting of steel [4]. Among many main roles of mold

* Corresponding author.

E-mail: arefpour.a@gmail.com powder, protection of molten steel surface from oxidation, thermal insulation, lubrication and heat transfer control between the shell and the mold through solidified steel shell can be mentioned [5-7]. $\mathrm{F}^{-}$is one of the important constitutive constituents in mold powder, which is added through such constituents as calcium fluoride $\left(\mathrm{CaF}_{2}\right)$ and $\mathrm{NaF}$ into mold powder $[8,9]$. The main duties of $\mathrm{F}^{-}$in mold powder are to reduce melting temperature, optimize viscosity and make crystalline particles in slag film $[10,11]$. In other 
words, $\mathrm{F}^{-}$reduces melting temperature and optimizes mold powder viscosity. However, emission of toxic materials from mold powder which contains $\mathrm{F}^{-}$in cooling water and its destructive impacts on environment have led to a universal concern over finding new substitutions for $\mathrm{F}^{-}$with less damage during recent years [12]. Emission of toxic constituents containing $\mathrm{F}^{-}$such as $\mathrm{HF}, \mathrm{SiF}_{4}$, etc., has been one of the greatest environmental challenges, because these constituents are dissolved in cooling water, acidifying the water which leads to equipment corrosion in industrial plants and poisoning the water and soil which subsequently endangers the safety and security of the environment $[13,14]$. The major aim of this research is to evaluate the effects of $\mathrm{CaF}_{2}$ and manganese oxide $(\mathrm{MnO})$ on the crystallization of the mold powder. Therefore, in order to study the crystallization of the original mold powder and the prepared samples, simultaneous thermal analysis (STA) as well as X-ray diffraction (XRD) were performed.

\section{Experiments}

\section{1 Sample preparation}

In this research, the chosen sample powder, called original mold powder, whose chemical compounds are given in Table 1, were used in high-speed continuous casting of steel. To provide laboratory samples, such materials as $\mathrm{SiO}_{2}, \mathrm{Na}_{2} \mathrm{CO}_{3}, \mathrm{MgO}, \mathrm{MnO}, \mathrm{CaF}_{2}$ and Portland cement clinker were used. The Portland cement clinker's chemical compounds are indicated in Table 2. Six powder samples, each weighing $50 \mathrm{~g}$ and whose chemical constituents are based on gram according to Table 3, were prepared. The chemical constituents of these prepared samples based on weight percentage are indicated in Table 4. In order to mix and homogenize the samples, ethanol and grinding mill were used. Each sample weighing $50 \mathrm{~g}$ was combined with $50 \mathrm{~g}$ of ethanol with $96 \%$ of purity, mixed in a ball mill for $5 \mathrm{~min}$ with $600 \mathrm{rpm}$. Then to the dry powder samples and vaporize ethanol, all six samples were put into drier for $3 \mathrm{~h}$ at $110{ }^{\circ} \mathrm{C}$, and finally they were dried in the drier under the temperature of $110{ }^{\circ} \mathrm{C}$.

Table 1 Chemical compounds of the reference powder in terms of weight percentage

\begin{tabular}{cc}
\hline Chemical composition & Weight percentage $(\mathrm{wt} \%)$ \\
\hline Loss on ignition & $15-18$ \\
$\mathrm{C}_{\text {(total) }}$ & $7-9$ \\
$\mathrm{C}_{\text {(free) }}$ & $4.5-6.5$ \\
$\mathrm{SiO}_{2}$ & $28-29.5$ \\
$\mathrm{Fe}_{2} \mathrm{O}_{3}$ & $1-2.5$ \\
$\mathrm{Al}_{2} \mathrm{O}_{3}$ & $3-5$ \\
$\mathrm{CaO}$ & $26-28$ \\
$\mathrm{MgO}$ & $5-6$ \\
$\mathrm{Na}_{2} \mathrm{O}+\mathrm{K}_{2} \mathrm{O}$ & $6-8$ \\
$\mathrm{MnO}$ & $4-6$ \\
$\mathrm{Fluorine}^{-}\left(\mathrm{F}^{-}\right)$ & $3-4$ \\
$\mathrm{~S}$ & $<0.3$ \\
$\mathrm{H}_{2} \mathrm{O}\left(120{ }^{\circ} \mathrm{C}\right)$ & $<0.8$ \\
\hline
\end{tabular}

Table 2 Chemical analysis of Portland cement clinker in terms of weight percentage

\begin{tabular}{cc}
\hline Chemical composition & Weight percentage (wt\%) \\
\hline $\mathrm{SiO}_{2}$ & 21.78 \\
$\mathrm{Al}_{2} \mathrm{O}_{3}$ & 5.41 \\
$\mathrm{Fe}_{2} \mathrm{O}_{3}$ & 3.14 \\
$\mathrm{CaO}$ & 64.32 \\
$\mathrm{MgO}$ & 1.89 \\
$\mathrm{~K}_{2} \mathrm{O}$ & 0.73 \\
$\mathrm{Na}_{2} \mathrm{O}$ & 0.28 \\
$\mathrm{SO}_{3}$ & 0.01 \\
\hline
\end{tabular}

Table 3 Chemical compounds of samples A to $F$

(Unit: g)

\begin{tabular}{ccccccc}
\hline & $\begin{array}{c}\text { Portland cement } \\
\text { clinker }\end{array}$ & $\mathrm{SiO}_{2}$ & $\mathrm{MnO}$ & $\mathrm{MgO}$ & $\mathrm{Na}_{2} \mathrm{CO}_{3}$ & $\mathrm{CaF}_{2}$ \\
\hline $\mathrm{A}$ & 22.82 & 10.64 & 2.97 & 2.36 & 7.26 & 4.10 \\
$\mathrm{~B}$ & 22.82 & 10.64 & 2.97 & 2.36 & 7.26 & 3.08 \\
$\mathrm{C}$ & 22.82 & 10.64 & 2.97 & 2.36 & 7.26 & 2.05 \\
$\mathrm{D}$ & 22.82 & 10.64 & 2.97 & 2.36 & 7.26 & 1.02 \\
$\mathrm{E}$ & 22.82 & 10.64 & 4.97 & 2.36 & 7.26 & 2.05 \\
$\mathrm{~F}$ & 22.82 & 10.64 & 5.47 & 2.36 & 7.26 & 1.02 \\
\hline
\end{tabular}

Table 4 Chemical compounds of samples A to $\mathbf{F}$

\begin{tabular}{cccccccccccc}
\hline & $\mathrm{CaO}$ & $\mathrm{SiO}_{2}$ & $\mathrm{Al}_{2} \mathrm{O}_{3}$ & $\mathrm{Fe}_{2} \mathrm{O}_{3}$ & $\mathrm{MnO}$ & $\mathrm{MgO}$ & $\mathrm{Na}_{2} \mathrm{O}$ & $\mathrm{K}_{2} \mathrm{O}$ & $\mathrm{F}^{-}$ & $\mathrm{C}$ & $\mathrm{S}$ \\
\hline $\mathrm{A}$ & 36.52 & 32.36 & 2.56 & 1.48 & 6.16 & 5.78 & 8.94 & 0.34 & 4.14 & 1.70 & 0.004 \\
$\mathrm{~B}$ & 35.92 & 33.21 & 2.63 & 1.52 & 6.33 & 5.93 & 9.20 & 0.35 & 3.19 & 1.74 & 0.004 \\
$\mathrm{C}$ & 35.30 & 34.10 & 2.70 & 1.56 & 6.50 & 6.09 & 9.42 & 0.36 & 2.18 & 1.79 & 0.004 \\
$\mathrm{D}$ & 34.60 & 35.05 & 2.77 & 1.60 & 6.68 & 6.26 & 9.70 & 0.37 & 1.12 & 1.84 & 0.004 \\
$\mathrm{E}$ & 33.80 & 32.70 & 2.60 & 1.50 & 10.41 & 5.84 & 9.03 & 0.34 & 2.09 & 1.72 & 0.004 \\
$\mathrm{~F}$ & 32.76 & 33.20 & 2.62 & 1.52 & 11.64 & 5.93 & 9.17 & 0.35 & 1.06 & 1.74 & 0.004 \\
\hline
\end{tabular}




\section{2 Simultaneous thermal analysis}

STA was used to determine melting and crystallization temperatures of the original mold powder in addition to those of the simulated original mold powder (sample A) and the less- $\mathrm{F}^{-}$sample of the mold powder using manganese oxide (sample E). This analysis was performed in argon atmosphere, and the heating speed was selected to $20{ }^{\circ} \mathrm{C} / \mathrm{min}$. The original mold powder and samples $\mathrm{A}$ and $\mathrm{E}$ were heated up to $1250{ }^{\circ} \mathrm{C}$.

\section{$2.3 \mathrm{X}$-ray diffraction analysis}

XRD analysis was used to recognize the original mold powder and to determine crystalline phases which were obtained after STA in the original mold powder and samples A and E. In this step, an XRD device was used.

\section{Results and discussion}

Prior to preparing the laboratory samples and comparing them with the original mold powder (industrial mold powder, which has also been used as reference powder in this research), XRD and STA analyses were performed. The former is to determine the existing phases in the powder, and the latter is to determine its melting and crystallization temperatures. XRD analysis of the original mold powder reveals wollastonite $\left(\mathrm{CaSiO}_{3}\right)$, silica $\left(\mathrm{SiO}_{2}\right), \mathrm{Na}_{2} \mathrm{CO}_{3}, \mathrm{CaF}_{2}$, corundum $\left(\mathrm{Al}_{2} \mathrm{O}_{3}\right), \quad \mathrm{MnSiO}_{3}, \quad \mathrm{CaMg}\left(\mathrm{SiO}_{3}\right)_{2}$ and $\mathrm{CaAl}_{2} \mathrm{O}_{4}$ phases. Considering the intensity of the peaks in the XRD analysis, the wollastonite phase proves to have the highest peak in comparison to other phases. In other words, wollastonite has formed the main compound of the original mold powder. Figure 1 presents the XRD analysis of the original mold powder.

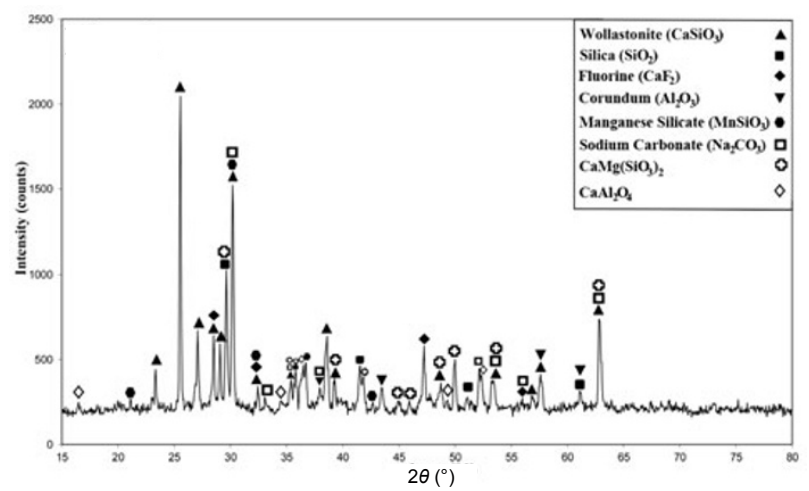

Fig. 1 XRD analysis of the original mold powder to recognize the phases.
Subsequently, in order to determine melting and crystallization temperatures of the original mold powder, the sample was analyzed by STA in powder form.

The thermal gravimetric analysis (TGA) of the original mold powder demonstrates a constant reduction in weight from $200{ }^{\circ} \mathrm{C}$ to $1200{ }^{\circ} \mathrm{C}$ (Fig. 2), which seems to be due to carbon burning or $\mathrm{CO}_{2}$ enhancement since carbon is an independent element. In other words, carbon does not have any cooperative bond $(\mathrm{C}-\mathrm{C})$ with any oxides. The differential thermal analysis (DTA) of the original mold powder during heating reveals the exothermic trough at $550{ }^{\circ} \mathrm{C}$ which is believed to be due to carbon burning (Fig. 2). At $700{ }^{\circ} \mathrm{C}$, the endothermic trough is observed which seems to be related to $\mathrm{CO}_{2}$ gas release. At the temperature of $1150{ }^{\circ} \mathrm{C}$, another endothermic trough is seen which shows the original mold powder's melting temperature. After reaching the temperature of $1250{ }^{\circ} \mathrm{C}$, the cooling process begins, and at the temperature of $1250{ }^{\circ} \mathrm{C}$, an endothermic trough is observed which shows to be the crystallization temperature of the original mold powder. This temperature has been the beginning of crystallization of phases. In other words, with the formation of crystalline sediments between the copper mold and the solidified steel shell at this temperature, the mold powder viscosity will be optimized ("optimize" and "optimum" attributed to viscosity in this paper are aimed to refer to a balanced level of viscosity, neither decreased nor increased). In order for the crystalline phases to be determined in the original mold powder after STA, the XRD analysis was performed which reveals such crystalline phases as gehlenite $\left(\mathrm{Ca}_{2} \mathrm{Al}_{2} \mathrm{SiO}_{7}\right)$, cuspidine $\left(\mathrm{Ca}_{4} \mathrm{~F}_{2} \mathrm{Si}_{2} \mathrm{O}_{7}\right)$, akermanite $\left(\mathrm{Ca}_{2} \mathrm{MgSi}_{2} \mathrm{O}_{7}\right)$, nepheline $\left(\mathrm{NaA}_{1} \mathrm{SiO}_{4}\right)$ and $\mathrm{Mn}_{3} \mathrm{O}_{4}$ (Fig. 3). In the original mold powder, wollastonite, as the most significant available compound in the powder, has been melted accompanied with other constituents. During the process of solidification, other phases such as gehlenite, cuspidine, akermanite, nepheline and $\mathrm{Mn}_{3} \mathrm{O}_{4}$ are obtained from primary fusion and these crystalline phases will lead to the viscosity of the mold powder. The results of STA of sample A in powder form prove the TGA to demonstrate the exhaust of $\mathrm{CO}_{2}$ within the temperature range of $200{ }^{\circ} \mathrm{C}$ to $1200{ }^{\circ} \mathrm{C}$ (Fig. 4). This, in sample A, has been due to using less amount of carbonate in the first place and using Portland cement clinker in the second in the compounds of the mold powder. The application of Portland cement clinker is regarded as an upside 
continuous casting since it reduces $\mathrm{CO}_{2}$ exhaust to minimum and decreases thermal loss. The relation defined for thermal loss percentage from TGA is as follows:

$$
\text { Loss on ignition }(\mathrm{LOI})=\frac{\mid \text { Amont of weight decrease } \mid}{\text { Total weight of the sample }}
$$

"Loss on ignition" abbreviated as "LOI" is also referred to as "thermal loss" in this paper.

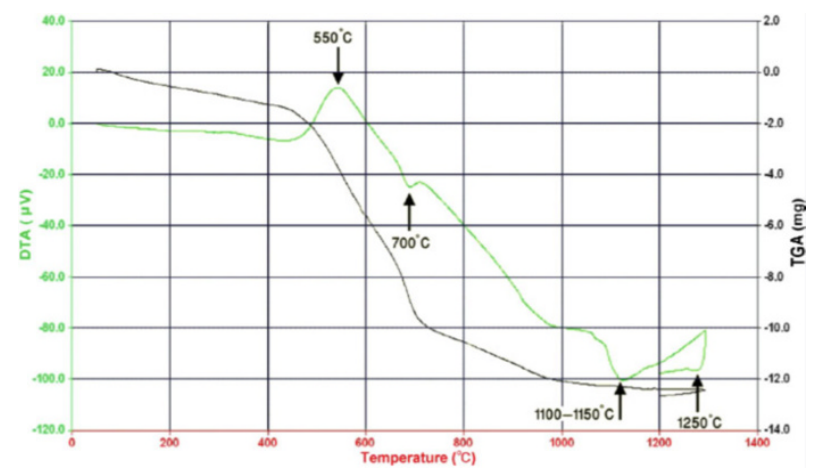

Fig. 2 STA of the original mold powder.

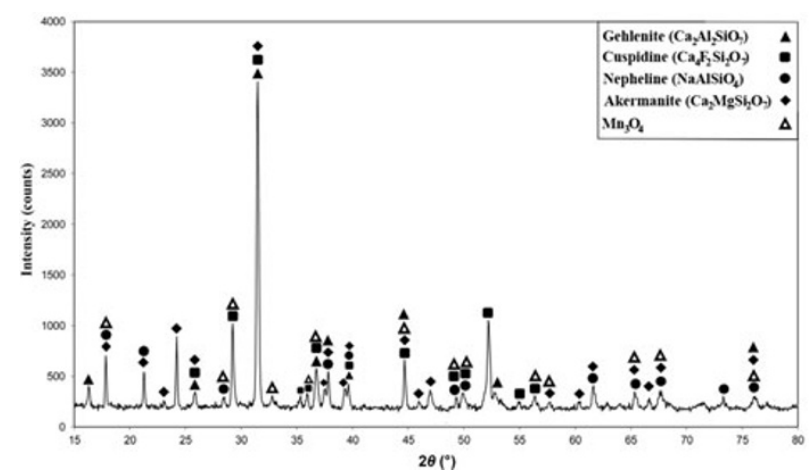

Fig. 3 Post-STA XRD analysis of the original mold powder.

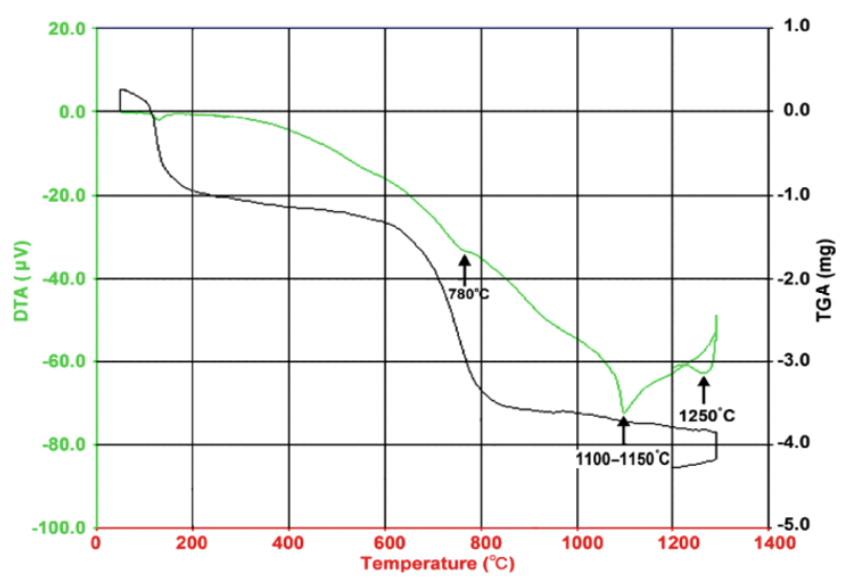

Fig. 4 STA of sample A.
In sample $\mathrm{A}$, the amount of weight reduction is $2.8 \mathrm{mg}$ and the total weight of the sample is $32.52 \mathrm{mg}$; therefore, the thermal loss in this sample is $8.6 \mathrm{wt} \%$ which is considerably less than the thermal loss in the original mold powder. The DTA of sample A during heating does not demonstrate a peak for carbon burning; however, a short endothermic trough is revealed at the temperature of $780{ }^{\circ} \mathrm{C}$ which is believed to be due to $\mathrm{CO}_{2}$ release (Fig. 4). In the thermal range of $1100-1150{ }^{\circ} \mathrm{C}$, another endothermic trough is shown which is the melting temperature of sample A. The endothermic trough in the melting temperature of sample A has had much similarity to the endothermic trough in the melting temperature of the original mold powder. During the cooling process of sample A, an endothermic trough has been observed at the temperature of $1250{ }^{\circ} \mathrm{C}$ which is believed to be the crystallization temperature of sample A being the beginning of crystallization of phases. As already explained, the mold powder viscosity will be optimized with the formation of crystalline sediments between the copper mold and the solidified steel shell at the temperature of $1250{ }^{\circ} \mathrm{C}$. Such crystalline phases as gehlenite, cuspidine, akermanite, nepheline and $\mathrm{Mn}_{3} \mathrm{O}_{4}$ are determined in XRD analysis of sample A which has been provided after STA (Fig. 5). The above-mentioned phases are also determined in the post-STA XRD analysis of the original mold powder; however, other than these phases, $\mathrm{Ca}_{3} \mathrm{SiO}_{5}$ is also observed in this analysis. Thus, it can be concluded that sample A could be a suitable laboratory-scale substitution for original mold powder. Figure 5 shows the XRD analysis of sample A after STA. The results of STA performed on sample E, analyzed in powder form, show that the TGA of this sample has proved the weight reduction due to $\mathrm{CO}_{2}$ release within the temperature range of $200{ }^{\circ} \mathrm{C}$ to $1200{ }^{\circ} \mathrm{C}$ (Fig. 6). The similar occurrence is also observed in sample A. According to Eq. (1) defined for thermal loss percentage, the weight reduction rate is $3.8 \mathrm{mg}$ and the total weight of the sample is $41.25 \mathrm{mg}$ in this sample. Therefore, the thermal loss in this sample is $9.2 \mathrm{wt} \%$ which is much less than the thermal loss in the original mold powder. The DTA of sample E (Fig. 6) has not shown any peak for carbon burn during the heating process. However, at the temperature of $780{ }^{\circ} \mathrm{C}$, a short endothermic trough is observed which is believed to be due to $\mathrm{CO}_{2}$ release. At the temperature of $1150{ }^{\circ} \mathrm{C}$, another endothermic trough is revealed which is the melting temperature of sample E. This peak 
representing the melting temperature in the DTA of sample E has considerable conformity to that of the original mold powder. The DTA of sample E during the cooling process shows an endothermic trough at the temperature of $1250{ }^{\circ} \mathrm{C}$ which is believed to be the crystallization temperature of sample E. Phases begin the process of crystallization at this temperature, i.e., $1250{ }^{\circ} \mathrm{C}$. The crystallization temperature trough of sample $\mathrm{E}$ also has similarity to that of the original mold powder. Considering this similarity between the melting and crystallization temperatures of sample $\mathrm{E}$ and those of the original mold powder, it can be concluded that sample E (less- $\mathrm{F}^{-}$sample) is potential laboratory-scale substitution for the original mold powder. The post-STA XRD analysis of sample E was performed which shows such crystalline phases as gehlenite, cuspidine, akermanite, nepheline, $\mathrm{Mn}_{3} \mathrm{O}_{4}$ and $\mathrm{Ca}_{3} \mathrm{SiO}_{5}$ (Fig. 7). A combination of these crystalline phases such as cuspidine could lead to the optimum of mold powder viscosity.

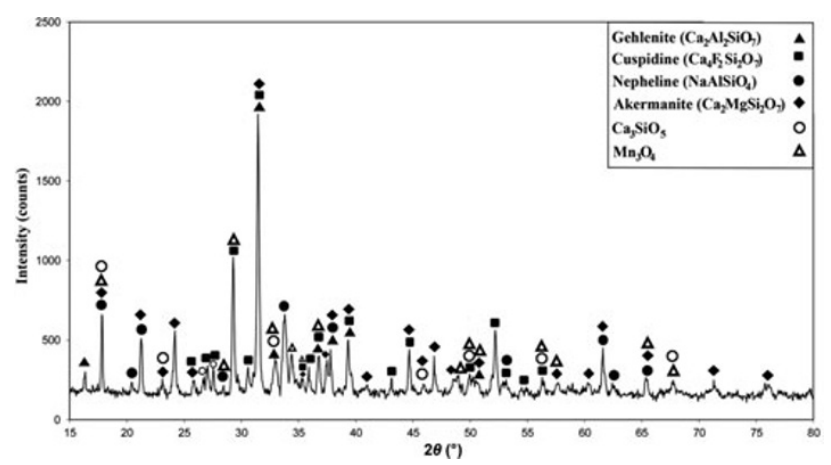

Fig. 5 Post-STA XRD analysis of sample A.

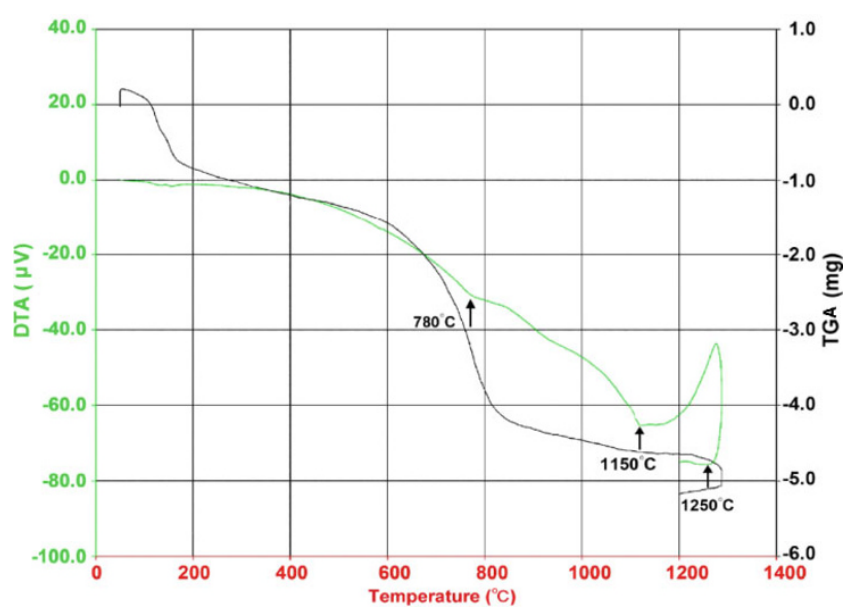

Fig. 6 STA of sample E.

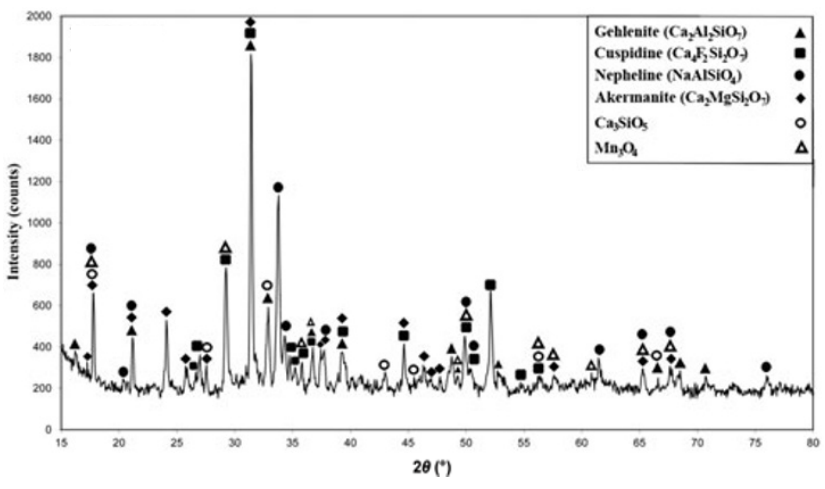

Fig. 7 Post-STA XRD analysis of sample E.

\section{Conclusions}

(1) Considering the TGA results of the original mold powder and samples A and E, comparing them to each other, and calculating their thermal loss with the consideration of the decrease in thermal loss of samples $\mathrm{A}$ and $\mathrm{E}$ in comparison with that of the original mold powder in laboratory, it can be concluded that Portland cement clinker might be a potential basic component in the chemical compounds of mold powder in laboratory and industrial tests.

(2) Considering the melting and crystallization temperatures of samples A and E in DTA and their comparison to those of the original mold powder, it can be concluded that samples A and E, as laboratory samples of the mold powder, have similar melting and crystallization temperatures as those of the original mold powder.

(3) Considering the XRD analyses of samples A and $E$ as well as the XRD analysis of the original mold powder, which were performed after STA, a combination of such crystalline phases as gehlenite, cuspidine, akermanite, nepheline and $\mathrm{Mn}_{3} \mathrm{O}_{4}$ was revealed. Considering the similarity between these phases in the original mold powder after STA and those in the XRD analyses of samples A and E after STA, it can be concluded that samples A and $\mathrm{E}$ are two acceptable laboratory-scale samples of mold powder for continuous casting of steel regarding STA and XRD analyses.

Open Access: This article is distributed under the terms of the Creative Commons Attribution License which permits any use, distribution, and reproduction 
in any medium, provided the original author(s) and the source are credited.

\section{References}

[1] Kondratiev A, Hayes PC, Jak E. Development of a quasi-chemical viscosity model for fully liquid slags in the $\mathrm{Al}_{2} \mathrm{O}_{3}-\mathrm{CaO}-\mathrm{FeO}-\mathrm{MgO}-\mathrm{SiO}_{2}$ system. Part 3. Summary of the model predictions for the $\mathrm{Al}_{2} \mathrm{O}_{3}-\mathrm{CaO}-\mathrm{MgO}-\mathrm{SiO}_{2}$ system and its sub-systems. ISIJ Int 2006, 46: 375-384

[2] Kondratiev A, Hayes PC, Jak E. Development of a quasi-chemical viscosity model for fully liquid slags in the $\mathrm{Al}_{2} \mathrm{O}_{3}-\mathrm{CaO}-\mathrm{FeO}-\mathrm{MgO}-\mathrm{SiO}_{2}$ system. Part 2. A review of the experimental data and the model predictions for the $\mathrm{Al}_{2} \mathrm{O}_{3}-\mathrm{CaO}-\mathrm{MgO}$, $\mathrm{CaO}-\mathrm{MgO}-\mathrm{SiO}_{2}$ and $\mathrm{Al}_{2} \mathrm{O}_{3}-\mathrm{MgO}-\mathrm{SiO}_{2}$ systems. ISIJ Int 2006, 46: 368-374.

[3] Kondratiev A, Hayes PC, Jak E. Development of a quasi-chemical viscosity model for fully liquid slags in the $\mathrm{Al}_{2} \mathrm{O}_{3}-\mathrm{CaO}-\mathrm{FeO}-\mathrm{MgO}-\mathrm{SiO}_{2}$ system. Part 1 . Description of the model and its application to the $\mathrm{MgO}, \mathrm{MgO}_{2}-\mathrm{SiO}_{2}, \mathrm{Al}_{2} \mathrm{O}_{3}-\mathrm{MgO}$ and $\mathrm{CaO}-\mathrm{MgO}$ sub-systems. ISIJ Int 2006, 46: 359-367.

[4] Nakamoto M, Lee J, Tanaka T. A model for viscosity of estimation of molten silicate slag. ISIJ Int 2005, 45: 651-656.

[5] Nakamoto M, Miyabayashi Y, Holappa L, et al. A model for estimating viscosities of aluminosilicate melts containing alkali oxides. ISIJ Int 2007, 47: 1409-1415.
[6] Wen G, Sridhar S, Tang P, et al. Development of fluoride-free mold powder for peritectic steel slab casting. ISIJ Int 2007, 47: 1117-1125.

[7] Cho JW, Emi T, Shibata H, et al. Heat transfer across mold flux film in mold during initial solidification in continuous casting of steel. ISIJ Int 1998, 38: 834-842.

[8] Nakajima K. Heat transfer and lubrication behavior in mold at high-speed continuous casting of steel slabs. CAMP-ISIJ 1992, 5: 1221-1224.

[9] Mills KC, Fox AB. The role of mould fluxes in continuous casting - so simple yet so complex. ISIJ Int 2003, 43: 1479-1486.

[10] Fox AB, Mills KC, Lever D, et al. Development of fluoride-free fluxes for billet casting. ISIJ Int 2005, 45: 1051-1058.

[11] Cramb AW. Strip casting: Anticipating new routes to steel sheet. Project proposal to AISI. Pittsburgh (US): Carnegie Mellon University, 1998.

[12] Choi SY, Lee DH, Shin DW, et al. Properties of F-free glass system as a mold flux: Viscosity, thermal conductivity and crystallization behavior. J Non-Cryst Solids 2004, 345-346: 157-160.

[13] Wang W, Blazek K, Cramb A. A study of the crystallization behavior of a new mold flux used in the casting of transformation-induced-plasticity steels. Metall Mater Trans B 2008, 39: 66-74.

[14] Yamauchi A, Sorimachi K, Yamauchi T. Effect of solidus temperature and crystalline phase of mould flux on heat transfer in continuous casting mould. Ironmak Steelmak 2002, 29: 203-207. 